AGRITECH, Vol. 37, No. 1, Februari 2017, Hal. 1-6 DOI: http://dx.doi.org/10.22146/agritech.16994 ISSN 0216-0455 (Print), ISSN 2527-3825 (Online)

Tersedia online di https://jurnal.ugm.ac.id/agritech/

\title{
Potensi Hipolipidemik Yogurt dari Isolat Protein Biji Kecipir (Psophocarpus tetragonolobus) pada Tikus Hiperkolesterol dengan Perlakuan Jumlah Pakan
}

\author{
Hypolipedemic Potencial of Yogurt from Protein Isolate of Winged Bean (Psophocarpus tetragonolobus) \\ in Hypercholesterol Rats with The Amount of Feed Treatment
}

\author{
Agus Slamet, Bayu Kanetro \\ Program Studi Teknologi Hasil Pertanian, Fakultas Agroindustri, Universitas Mercu Buana \\ J1. Wates Km. 10 Yogyakarta 55753, Indonesia \\ Email: agusumby@yahoo.com
}

Submisi: 16 November 2015; Penerimaan: 4 April 2016

\begin{abstract}
ABSTRAK
Biji kecipir memiliki kadar protein yang hampir sama dengan kedelai, namun bau langunya lebih tajam daripada kedelai, sehingga perlu diisolasi proteinnya sebelum digunakan sebagai bahan baku yogurt. Tujuan penelitian ini adalah menentukan potensi hipokolesterolemik yogurt isolat proteun biji kecipir melalui uji biologis in vivo menggunakan tikus jantan Sprague Dawley. Perlakuan penelitian ini adalah perlakuan pakan yogurt dengan konsentrasi 0 (pakan standar tanpa penambahan yogurt sebagai kontrol), 2, dan $4 \mathrm{~g}$ yogurt/hari berturut-turut sebagai perlakuan konsentrasi rendah dan tinggi selama 4 minggu perlakuan pakan yogurt sesudah pemberian pakan hiperkolesterol selama 1 minggu. Profil lipida darah tikus meliputi kadar trigliserida, total kolesterol, kolesterol High Density Lipoprotein (HDL), dan Low Density Lipoprotein (LDL) dianalisis pada minggu ke 2 dan 4 minggu selama perlakuan pakan yogurt dan sebelum perlakuan pakan yogurt yaitu pada fase pemeliharaan adaptasi dan 1 minggu pada fase pemeliharan hiperkolesterol. Hasil penelitian ini menunjukkan bahwa trigliserida, total kolesterol, dan kolesterol LDL meningkat dan kolesterol HDL menurun selama fase pemberian pakan hiperkolesterol sebelum perlakuan pakan yogurt. Potensi hipokolesterol yogurt isolat protein biji kecipir ditunjukkan dengan penurunan trigliserida, total kolesterol, dan kolesterol LDL, serta peningkatan kolesterol HDL sesudah perlakuan pakan yogurt dengan konsentrasi rendah maupun tinggi. Hal tersebut mengindikasikan bahwa yogurt isolat protein biji kecipir mampu menurunkan kolesterol
\end{abstract}

Kata kunci: Hipokolesterol; isolat protein; kecipir; yogurt

\begin{abstract}
Protein content of winged bean is almost the same as soybean, but the beany flavor is more poweful than soybean. Therefore the protein of winged bean was isolated prior to use as raw material of yogurt. This research was aimed to determine the potency of hypocholestrolemic activity of yogurt protein isolate of winged bean through in vivo bioassay by using Sprague Dawley male rats. The treatments of the research were yogurt feed treatment with concentration of yogurt 0 (standard feed without yogurt as a control), 2 , and $4 \mathrm{~g}$ yogurt/day as low and high concentration treatment respectively for $4^{\text {th }}$ weeks after hypercholesterol feed treatment for 1 week. The blood lipid profile of rats, including triglyceride, cholesterol total, High Density Lipoprotein (HDL), Low Density Lipoprotein (LDL) cholesterol were analysed on the $2^{\text {nd }}$ and $4^{\text {th }}$ weeks for the yogurt feed treatment while for before yogurt feed treatment, the evaluation were based on the adaptation phase and the 1st week for hypercholesterol phase. The result of this research showed that the blood triglyceride, cholesterol total, LDL increased, and the blood HDL decreased in hypercholesterol phase before
\end{abstract}


yogurt feed treatment. The potency of hypocholestrolemic of yogurt from protein isolate of winged bean was shown by the decreasing of blood triglyceride, cholesterol total, LDL and increasing the HDL cholesterol after the yogurt feed treatment with low and high concentration. That indicated that yogurt that was made of protein isolate of winged bean could reduced cholesterol.

Keywords: Hypocholesterolemic; protein isolate; winged bean; yogurt

\section{PENDAHULUAN}

Peningkatan kesejahteraan masyarakat, selalu diikuti dengan perubahan pola konsumsi. Perubahan pola makan kearah konsumsi tinggi lemak berakibat pada peningkatan kadar kolesterol dalam darah, atau hiperkolesterolemia. Indonesia pada saat ini menunjukkan kejadian penderita hiperkolesterolemia yang semakin meningkat. Hal ini diketahui dengan semakin meningkatnya penderita stroke, hipertensi dan penyakit jantung koroner (Purwanto, 2001). Angka kejadian stroke di Indonesia meningkat dengan tajam. Bahkan saat ini Indonesia merupakan negara dengan jumlah penderita stroke terbesar di Asia. Sudomo (2007), menyebutkan bahwa setiap tahun terjadi 500.000 penduduk terkena serangan stroke, sekitar 2,5\% atau 125.000 orang meninggal dan sisanya cacat ringan atau berat.

Hiperlipidemia/hiperkolesterolemia berkaitan erat dengan keadaan atherosklerosis yang merupakan penyebab timbulnya penyakit kardiovaskuler (Purwanto, 2008). Di Indonesia penyakit kardiovaskuler merupakan penyebab kematian nomor satu pada orang dewasa (usia di atas 35 tahun) untuk wilayah perkotaan atau sekitar $31 \%$ dari total penyebab kematian. Berdasarkan laporan Badan Kesehatan Dunia (2002), tercatat 4,4 juta kematian disebabkan oleh hiperkolesterol, atau 7,9 \% dari total kematian di usia muda.

Pencegahan peningkatan kadar kolesterol darah mulai mendapatkan perhatian dari masyarakat. Pencegahan hiperlipidemia secara gizi dilakukan dengan mengurangi konsumsi lemak jenuh, kolesterol, gula, alkohol dan memperbanyak konsumsi serat pangan (Purwanto, 2008). Pencegahan menggunakan bahan alami dapat dilakukan dengan konsumsi yogurt secara rutin.

Yogurt adalah makanan hasil fermentasi yang bermanfaat sebagai probiotik. Pangan probiotik berpotensi menurunkan kadar kolesterol darah. Hal ini dinyatakan oleh beberapa peneliti (Drake dkk., 2000; Lin dkk., 2005; Larkin dkk., 2007; Rossi dkk., 2005). Pada umumnya yogurt dibuat dari susu hewani, akan tetapi susu nabati dari kacangkacangan juga berpotensi sebagai bahan pembuatan yogurt. Hipokolesterolemik yogurt susu nabati dari kacang-kacangan kemungkinan lebih baik dari susu hewani. Protein kacangkacangan telah diketahui lebih bersifat hipokolesterolemik dari pada protein susu hewani ditinjau dari rasio argininlisinnya yang lebih besar daripada protein susu hewani atau kasein (Damasceno dkk., 2000). Pada pengujian biologis secara in vivo diketahui bahwa protein kacang tunggak juga bersifat hipokolesterolemik (Kanetro, 2015).

Murti (2006), menyatakan bahwa yogurt berbahan baku susu kedelai yang difermentasi dengan Streptococcus thermopillus dan Lactobacillus bulgaricus akan menghasilkan yogurt dengan tolal bakteri asam laktat 1,5 × $10^{6} \mathrm{sel} / \mathrm{g}$ yang berpotensi sebagai minuman probiotik/makanan fungsional.

Susu nabati yang banyak digunakan sebagai bahan pembuatan yogurt saat ini adalah susu kedelai. Padahal harga kedelai di pasaran saat ini sangat tinggi, disebabkan pemenuhan kebutuhan kedelai Indonesia sebagian besar adalah impor. Kebutuhan kedelai dalam negeri sebesar 1,8 juta ton/tahun, dengan pasokan impor 1,2 juta ton sementara produksi lokal hanya 620 ribu ton (Suara Pembaruan Daily, 2008).

Biji kecipir merupakan sumber protein nabati yang berpotensi sebagai bahan baku yogurt, karena berkadar protein tinggi (32,8 \%) setara dengan kadar protein kedelai $(35,1 \%)$ (Haryoto, 2002). Rasio arginin-lisin protein kecipir juga hampir sama dengan protein kedelai (Kanetro dan Dewi, 2013). Penelitian diarahkan untuk memanfaatkan biji kecipir sebagai bahan baku yogurt, namun berdasarkan penelitian sebelumnya diketahui susu kecipir yang dihasilkan berbangu langu. Oleh karenanya dalam penelitian digunakan isolat protein biji kecipir sebagai bahan baku yogurt. Tujuan penelitian ini adalah menentukan potensi hipokolesterolemik yogurt isolat protein biji kecipir melalui uji biologis in vivo menggunakan tikus jantan Sprague dawley.

\section{METODE PENELITIAN}

\section{Bahan}

Bahan utama penelitian ini adalah biji kacang kecipir (Psophocarpus tetragonolobus) diperoleh dari Toko Benih di Yogyakarta. Tikus Sprague dawley diperoleh dari UPHP UGM, Yogyakarta untuk pengujian biologis secara in vivo. Bahan-bahan kimia untuk pakan dan pengujian biologis secara in vivo, meliputi aloksan (Sigma), maizena, casein, vitamin mix, mineral mix, sukrosa, kolin bitartat, minyak kedelai, dan kholesterol kit (Diasys Diagnostic System GmBH \& $\mathrm{Co}$ ). Bahan kimia untuk isolasi protein yaitu $\mathrm{HCl}$ (Merck), dan $\mathrm{NaOH}$ (Merck). 


\section{Pembuatan Isolat Protein}

Pembuatan isolat protein biji kacang kecipir diawali dengan pensuspensian tepung biji dengan aquades (1:10), pengaturan $\mathrm{pH} 9$ untuk melarutkan protein dan sentrifigasi. Supernatan yang diperoleh merupakan larutan protein kemudian diatur pada $\mathrm{pH}$ isoelektris dan sentrifugasi. Endapan yang diperoleh dipisahkan selanjutnya dikeringkan untuk mendapatkan isolat protein kering yang digunakan sebagai bahan dasar yogurt.

\section{Pembuatan Yogurt}

Langkah-langkah tahap ini adalah sebagai berikut:

\section{Pembuatan starter induk}

Susu sapi segar sebanyak $20 \mathrm{ml}$ ditambah susu skim 4 $\%$ (b/v), kemudian dipasteurisasi selama 15 menit pada $90{ }^{\circ} \mathrm{C}$ setelah itu itu didinginkan $40^{\circ} \mathrm{C}$. Setelah itu dibagi menjadi 2 bagian (masing-masing $10 \mathrm{~mL}$ ), kemudian diinokulasi dengan kultur $S$. thermophillus sebanyak 3 ose ke dalam 10 media dan L. bulgaricus 3 ose ke dalam $10 \mathrm{ml}$ media (umur kultur murni 1 minggu setelah kultivasi dalam media MRS agar). Selanjutnya diinkubasi pada $37{ }^{\circ} \mathrm{C}$ selama 10 jam. Starter induk yang terbentuk kemudian dituang pada 25 $\mathrm{mL}$ susu sapi yang telah ditambah skim dan dipasteurisasi, kemudian diinkubasi pada $37^{\circ} \mathrm{C}$ selama 10 jam. Selanjutnya starter $25 \mathrm{~mL}$ yang terbentuk dituang pada $400 \mathrm{~mL}$ susu sapi dan diinkubasi pada $37^{\circ} \mathrm{C}$ selama 10 jam.

\section{Pembuatan yogurt isolat protein kecipir}

Pembuatan yogurt susu kecipir diawali dengan pembuatan isolat protein kecipir. Pembuatan isolat susu biji kecipir yaitu biji kecipir rendah lemak dilarutkan



Gambar 1. Diagram alir proses pembuatan yogurt dalam alkali ( $\mathrm{pH}$ 9) sehingga dihasilkan ekstrak dan residu/ ampas, ekstrak yang dihasilkan pH-nya diatur 4,5 yang menghasilkan gumpalan protein dan cairan, gumpalan protein yang dihasilkan dicuci dan dikeringkan. Diagram alir proses pembuatan yogurt disajikan pada Gambar 1 .

\section{Pengujian Biologis secara in vivo Profil Lipida Darah Yogurt Isolat Protein Biji Kecipir}

Sebanyak 18 ekor tikus, dibagi menjadi 3 kelompok. Kelompok 1 diberi pakan standar saja, kelompok ke 2 diberi pakan standar dan bubuk yogurt susu kacang kecipir konsentrasi rendah, kelompok 3 diberi pakan standar dan bubuk yogurt susu kacang kecipir konsentrasi tinggi. Diagram alir pengujian pengaruh yogurt isolat protein kecipir pada profil lipida darah hewan uji disajika pada Gambar 2.

Tikus dipelihara selama 4 hari sebagai masa adaptasi, selanjutnya diperlakukan kondisi hiperkolesterol dengan $10 \%$ lemak babi selama 7 hari. Perlakuan dengan yogurt susu kecipir dilakukan selama 2 minggu.

Pada akhir minggu ke 1 dan minggu ke 2, setelah pemberian yogurt yang berbeda konsentrasinya dilakukan uji profil lipida darah (meliputi: kadar kolesterol, kadar trigliserida, kadar HDL dan HDL).

Setelah tikus berada pada kondisi hiperkolesterol, selanjutnya dilakukan pembagian 18 hewan uji. Tikus diberi pakan dan air secara ad libitum. Pembagian kelompok tikus adalah sebagai berikut:

a. Kelompok 1: sebanyak 6 tikus diberi pakan standar, diberi air suling ad libitum, selama 2 minggu, profil lipida darah diuji setiap minggu.

b. Kelompok 2: sebanyak 6 tikus diberi pakan standar, diberi air suling ad libitum, dan diberi yogurt konsentrasi rendah, profil lipida darah diuji setiap minggu.

c. Kelompok 3: sebanyak 6 tikus diberi pakan standar, diberi air suling ad libitum, dan diberi yogurt konsentrasi tinggi, profil lipida darah diuji setiap minggu.

Uji profil lipida darah dilakukan dengan menggunakan

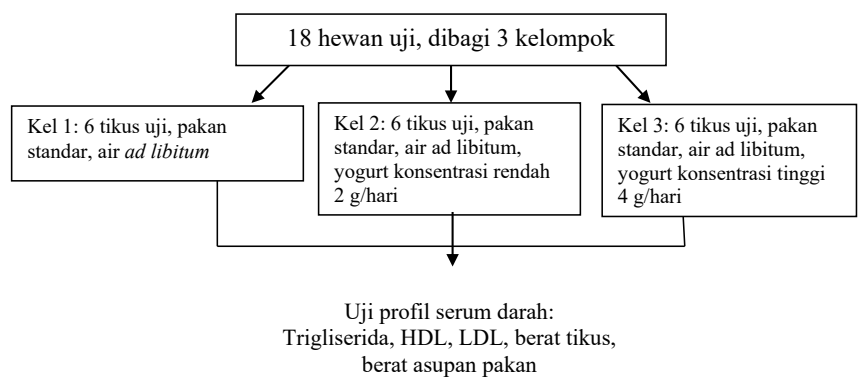

Gambar 2. Uji pengaruh yogurt isolat protein kecipir pada profil lipida darah hewan uji 
hewan uji tikus Sprague dawley yang diperlakukan dengan pakan hiperkolesterol selanjutnya diperlakukan dengan pakan yogurt isolat protein kecipir. Uji dilakukan terhadap profil total kolesterol, trigliserida, HDL dan LDL.

\section{HASIL DAN PEMBAHASAN}

\section{Total Kolesterol}

Pada Tabel 1, menunjukkan bahwa hasil uji statistik ada interaksi antar perlakuan (konsentrasi yogurt yang diberikan dan waktu pengamatan) terhadap profil total kolesterol hewan uji. Hewan uji yang tidak diperlakukan dengan yogurt susu kecipir, pada pengamatan minggu ke 4, profil total kolesterolnya tinggi $(233,86 \mathrm{mg} / \mathrm{dL})$. Sedangkan hewan uji yang diperlakuan dengan yogurt isolat protein kecipir (2 g/ hari) profil kolesterolnya lebih rendah, turun menjadi 144,18 $\%$. Perlakuan hewan uji dengan yogurt isolat protein kecipir ( $4 \mathrm{~g}$ /hari) tidak terlalu signifikan terhadap pengurangan profil total kolesterol lipida darah hewan uji. Terjadi penurunan total kolesterol $38 \%$, pada pemberian yogurt $2 \mathrm{~g}$ /hari dan penurunan sebesar $50 \%$, pada pemberian yogurt $4 \mathrm{~g} /$ hari.

Standar kolesterol normal menurut US National Cholesterol Education Program (NCEP) adalah kurang dari $200 \mathrm{mg} / \mathrm{dL}$ (Anonim, 2007). Berdasarkan data penelitian ini diketahui bahwa level kolesterol pada saat kondisi hiperkolesterol melebihi batas normal. Level kolesterol pada masa pemeliharaan selama 2 dan 4 minggu dengan pemberian pakan yogurt terbukti dapat menormalkan level koletsreol, seperi terlihat pada Tabel 1.

Comas dan Gilliland (2003) menyebutkan bahwa probiotik yang dibuat dari proses fermentasi dilaporkan dapat menurunkan profil kolesterol pada manusia. Mekanisme yang mungkin terjadi adalah terjadinya deconjugasi garam empedu di usus halus dengan adanya mikrobia probiotik. Pendapat lain menunjukkan bahwa peningkatan aktivitas bakteri probiotik akan menghasilkan produk yang dihasilkan selama fermentasi yang akan menghambat terbentuknya kolesterol di tubuh.

Tabel 1. Profil total kolesterol $(\mathrm{mg} / \mathrm{dL})$ pada perlakuan yogurt isolat protein kecipir

\begin{tabular}{lrrr}
\hline \multirow{2}{*}{ Perlakuan terhadap tikus } & \multicolumn{3}{c}{ Konsentrasi yogurt } \\
\cline { 2 - 4 } & $0 \mathrm{~g} / \mathrm{hari}^{\mathrm{y}}$ & $2 \mathrm{~g} / \mathrm{hari}$ & $4 \mathrm{~g} / \mathrm{hari}$ \\
\hline Masa adaptasi & $94,16^{\mathrm{a}}$ & $94,94^{\mathrm{a}}$ & $101,29^{\mathrm{b}}$ \\
Kondisi hiperkolesterol & $226,28^{\mathrm{g}}$ & $220,78^{\mathrm{f}}$ & $227,45^{\mathrm{hi}}$ \\
Pengamatan 2 minggu perlakuan & $231,88^{\mathrm{ij}}$ & $181,09^{\mathrm{e}}$ & $160,85^{\mathrm{d}}$ \\
Pengamatan 4 minggu perlakuan & $233,8^{6} \mathrm{j}$ & $144,18^{\mathrm{d}}$ & $116,21^{\mathrm{c}}$ \\
\hline
\end{tabular}

Keterangan: angka yang diikuti dengan huruf yang sama pada kolom dan baris yang sama menunjukkan tidak berbeda nyata pada uji statistik dengan DMRT tingkat kepercayaan $5 \%$.
Disamping itu rendahnya kolesterol, karena bakteri probiotik terjadi karena perbaikan metabolisme, pengurangan constipasi, meningkatkan sistem kekebalan, peningkatan toleransi phenol dan detoksifikasi potensi karsinogen.

\section{Trigliserida}

Pada Tabel 2. menunjukkan bahwa hasil uji statistik ada interaksi antar perlakuan (konsentrasi yogurt yang diberikan dan waktu pengamatan) terhadap profil trigliserida hewan uji. Hewan uji yang tidak diperlakukan dengan yogurt susu kecipir, pada pengamatan minggu ke 4, profil trigliserida tinggi $(178,20 \mathrm{mg} / \mathrm{dL})$. Sedangkan hewan uji yang diperlakukan dengan yogurt isolat protein kecipir (2 g/hari) profil kolesterolnya lebih rendah, turun menjadi 113,28 mg/ dL (sekitar $36 \%$ dari semula). Perlakuan hewan uji dengan yogurt isolat protein kecipir (4 g/hari) turun menjadi 88,22 $\mathrm{mg} / \mathrm{dL}$ (penurunan $50 \%$ ), lebih rendah dibanding perlakuan yogurt $2 \mathrm{~g} /$ hari.

Standar trigliserida normal menurut US National Cholesterol Education Program (NCEP) adalah kurang dari $150 \mathrm{mg} / \mathrm{dL}$ (Anonim, 2007). Berdasarkan data penelitian ini diketahui bahwa level trigliserida pada saat kondisi hiperkolesterol melebihi batas normal. Level trigliserida pada masa pemeliharaan selama 2 dan 4 minggu dengan pemberian pakan yogurt terbukti dapat menormalkan level trigliserida, seperi terlihat pada Tabel 2.

Profil trigliserida darah identik dengan profil kolesterol hewan uji. Dimungkinkan metabolit hasil fermentasi yang ada setelah proses pengeringan mampu menurunkan kadar trigliserida darah tikus percobaan.

Tabel 2 Profil trigliserida (mg/dL) pada perlakuan yogurt isolat protein kecipir

\begin{tabular}{lrrr}
\hline \multirow{2}{*}{ Perlakuan terhadap tikus } & \multicolumn{3}{c}{ Konsentrasi yogurt } \\
\cline { 2 - 4 } & $0 \mathrm{~g} / \mathrm{hari}^{\mathrm{a}}$ & $2 \mathrm{~g} / \mathrm{hari}$ & $4 \mathrm{~g} / \mathrm{hari}$ \\
\hline Masa adaptasi & $53,33^{\mathrm{a}}$ & $58,15^{\mathrm{b}}$ & $56,42^{\mathrm{ab}}$ \\
Kondisi hiperkolesterol & $173,23^{\mathrm{g}}$ & $177,20^{\mathrm{hi}}$ & $176,95^{\mathrm{hi}}$ \\
Pengamatan 2 minggu perlakuan & $175,12^{\mathrm{hi}}$ & $143,53^{\mathrm{f}}$ & $129,35^{\mathrm{e}}$ \\
Pengamatan 4 minggu perlakuan & $178,20^{\mathrm{i}}$ & $113,28^{\mathrm{d}}$ & $88,22^{\mathrm{c}}$ \\
\hline
\end{tabular}

Keterangan: angka yang diikuti dengan huruf yang sama pada kolom dan baris yang sama menunjukkan tidak berbeda nyata pada uji statistik dengan DMRT tingkat kepercayaan $5 \%$.

\section{HDL Kolesterol}

Pada Tabel 3, menunjukkan bahwa hasil uji statistik ada interaksi antar perlakuan (konsentrasi yogurt yang diberikan dan waktu pengamatan) terhadap profil HDL hewan uji. Hewan uji yang tidak diperlakukan dengan yogurt susu 
Tabel 3. Profil HDL (mg/dL) pada perlakuan yogurt isolat protein kecipir

\begin{tabular}{lrrr}
\hline \multirow{2}{*}{ Perlakuan terhadap tikus } & \multicolumn{3}{c}{ Konsentrasi yogurt } \\
\cline { 2 - 4 } & $0 \mathrm{~g} /$ hari $^{\mathrm{y}}$ & $2 \mathrm{~g} / \mathrm{hari}$ & $4 \mathrm{~g} / \mathrm{hari}$ \\
\hline Masa adaptasi & $114,70^{\mathrm{fg}}$ & $118,29^{\mathrm{hi}}$ & $116,84^{\mathrm{h}}$ \\
Kondisi hiperkolesterol & $43,85^{\mathrm{b}}$ & $43,18^{\mathrm{ab}}$ & $47,87 \mathrm{c}$ \\
Pengamatan 2 minggu perlakuan & $41,20^{\mathrm{ab}}$ & $58,25^{\mathrm{d}}$ & $69,33^{\mathrm{e}}$ \\
Pengamatan 4 minggu perlakuan & $39,34^{\mathrm{a}}$ & $84,91^{\mathrm{f}}$ & $111,26^{\mathrm{g}}$ \\
\hline
\end{tabular}

Keterangan: angka yang diikuti dengan huruf yang sama pada kolom dan baris yang sama menunjukkan tidak berbeda nyata pada uji statistik dengan DMRT tingkat kepercayaan $5 \%$.

kecipir, pada pengamatan minggu ke 4, profil HDL rendah $(39,34 \mathrm{mg} / \mathrm{dL})$. Sedangkan hewan uji yang diperlakuan dengan yogurt isolat protein kecipir $(2 \mathrm{~g} /$ hari $)$ profil HDL lebih tinggi, meningkat menjadi 84,91 mg/dL (meningkat 54 $\%$ ). Perlakuan hewan uji dengan yogurt isolat protein kecipir (4 g/hari), HDL meningkat menjadi 111,26 mg/dL (meningkat $65 \%$ ), lebih tinggi dibanding perlakuan yogurt $2 \mathrm{~g} / \mathrm{hari}$. Perlakuan pakan yogurt terbukti dapat memperbaiki level HDL sehingga hampir sama dengan masa adaptasi khususnya pada perlakuan pakan $4 \mathrm{~g}$ /hari pemeliharaan 4 minggu yang tidak berbeda nyata dengan masa adaptasi perlakuan pakan $0 \mathrm{~g}$ /hari. Standar HDL normal pada manusia menurut $U S$ National Cholesterol Education Program (NCEP) adalah lebih dari $60 \mathrm{mg} / \mathrm{dL}$ (Anonim, 2007) dan pada tikus lebih dari 45mg/dL (Herlina dkk., 2013).

HDL mempunyai fungsi mengangkut kelebihan kolesterol untuk dibawa ke jaringan hati dan selanjutnya akan diuraikan kemudian dibuang ke dalam kandung empedu sebagai asam (cairan empedu). HDL akan membersihkan kelebihan kolesterol dari dinding pembuluh darah dengan mengangkutnya kembali ke hati. Konsentrasi HDL yang tinggi menunjukkan pengaruh positif konsumsi bubuk yogurt pada profil lidida darah. Semakin besar konsentrasi HDL lipida darah akan memperkecil resiko terkena tekanan darah tinggi yang berakibat pada serangan stroke.

\section{LDL Kolesterol}

Pada Tabel 4, menunjukkan bahwa hasil uji statistik tidak ada interaksi antar perlakuan (konsentrasi yogurt yang diberikan dan waktu pengamatan) terhadap profil LDL hewan uji. Profil LDL lipida darah hewan uji tidak dipengaruhi oleh konsentrasi yogurt isolat protein kecipir yang diberikan. Hari pengamatan berpengaruh terhadap LDL profil lipida darah hewan uji. Apabila dibandingkan profil lipida darah hewan uji yang tidak diperlakukan dengan yogurt isolat protein kecipir, menunjukkan penurunan LDL yang cukup signifikan.
Tabel 4. Profil LDL (mg/dl) tikus dengan perlakuan yogurt isolat protein kecipir

\begin{tabular}{lrrrr}
\hline \multicolumn{1}{c}{$\begin{array}{c}\text { Perlakuan } \\
\text { terhadap tikus }\end{array}$} & \multicolumn{3}{c}{ Konsentrasi yogurt } & Rata- \\
\cline { 2 - 4 } & $0 \mathrm{~g} / \mathrm{hari}$ & $2 \mathrm{~g} /$ hari & $4 \mathrm{~g} / \mathrm{hari}$ & \multicolumn{1}{c}{ rata } \\
\hline Masa adaptasi & 32,72 & 36,72 & 35,28 & $34,91^{\mathrm{a}}$ \\
Kondisi hiperkolesterol & 147,12 & 148,35 & 151,44 & $148,98^{\mathrm{c}}$ \\
$\begin{array}{l}\text { Pengamatan 2 minggu } \\
\text { perlakuan }\end{array}$ & 148,70 & 127,10 & 118,69 & $131,49^{\mathrm{c}}$ \\
$\begin{array}{l}\text { Pengamatan 4 minggu } \\
\text { perlakuan }\end{array}$ & 151,20 & 81,09 & 65,10 & $89,02^{\mathrm{b}}$ \\
\hline
\end{tabular}

Pemberian pakan 2 g/hari pada hewan uji akan menurunkan profil LDL lipida darah sampai $46 \%$, sedangkan pemberian $4 \mathrm{~g}$ /hari akan menurunkan profil lipida darah hingga $57 \%$, sehingga perlakuan pakan yogurt terbukti dapat menormalkan level LDL. Standar LDL normal manusia adalah kurang dari $100 \mathrm{mg} / \mathrm{dL}$ (Anonim 2007), sedangkan pada tikus kurang dari $135 \mathrm{mg} / \mathrm{dL}$ (Herlina dkk., 2013). LDL mengandung lemak lebih banyak dari pada HDL, sehingga akan mengambang di dalam darah. LDL sering disebut sebagai lemak jahat karena dapat menyebabkan penempelan kolesterol di dinding pembuluh darah.

\section{KESIMPULAN}

Berdasarkan penelitian ini dapat disimpulkan bahwa potensi hipolipidemik yogurt isolat protein biji kecipir ditunjukkan dengan penurunan trigliserida, total kolesterol, dan kolesterol LDL, serta peningkatan kolesterol HDL sesudah perlakuan pakan yogurt dengan konsentrasi rendah maupun tinggi. Perubahan profil lipida darah sesudah pemberian pakan yogurt yaitu total kolesterol turun hingga 38 $\%$, trigliserida turun hingga $36 \%$, HDL meningkat hingga 54 $\%$ dan LDL turun sampai $46 \%$. Hal tersebut mengindikasikan bahwa yogurt isolat protein biji kecipir mampu menurunkan kolesterol.

\section{UCAPAN TERIMA KASIH}

Penulis mengucapkan terima kasih kepada Kementerian Riset, Teknologi dan Pendidikan Tinggi yang telah memberikan biaya penelitian melalui Program Hibah Bersaing tahun 2014.

\section{DAFTAR PUSTAKA}

Damasceno, N.R., Goto, H., Dias, M.D.R., Okawabata, F.S., Abdalia, S.P. dan Gidlund, M.A. (2000). Casein and soy protein isolate in experimental atherosclerosis influence 
on hyperlipidemia and lipoprotein oxidation. Annals of Nutrition and Metabolism 45: 38-46.

Drake, M.A., Chen, X.Q., Tamarapu dan Leenanon (2000). Soy protein fortification affect sensory, chemichal, and microbiological properties of dairy yogurt. Journal of Food Science 56: 4-12.

Haryoto (2000). Susu dan Yoghurt Kecipir. Kanisius, Yogyakarta.

Herlina, Harijono, Subagio, A. dan Estiasih, T. (2013). Potensi hipolipidemik polisakarida larut air umbi gembili (Dioscore esculenta L.) pada tikus hiperlipidemia. Agritech 33: 8-15.

Kanetro, B. dan Dewi, S.H.C. (2013). Pengaruh berbagai kecambah kacang-kacangan lokal sebagai bahan dasar meat analog terhadap sifat fisik (tekstur), kesukaaan, dan rasio arginin-lisin. Agritech 33: 1-7.

Kanetro, B. (2015). Hypocholesterolemic properties of protein isolate from cowpeas (Vigna ungucuilata) sprout in normal and diabetic rats. Procedia Food Science 3: 112-118.

Mc. Comas, K.A. dan Gilliland, S.E. (2003). Growth of probiotic and traditional yogurt cultures in milk supplemented with whey protein hydrolysate. Journal of Food Science 68: 2090-2095.
Murti, S.T.C. (2006). Pembuatan Bubuk Yogurt Susu Kedelai dengan Proses Pengeringan (Spray Drier) dan Penambahan Gum Arab. Laporan Penelitian Dosen Muda Direktorat Pendidikan Tinggi. Universitas Mercu Buana, Yogyakarta.

Nuraida, L. (1996). Minuman dan Makanan Fungsional: Bifidobakteria. Kursus Singkat "Makanan Fungsional dan Keamanan Pangan”. Pusat Antar Universitas Pangan dan Gizi. Universitas Gadjah Mada, Yogyakarta.

Purwanto, A. (2001). Efek Gizi Tempe terhadap Hiperlipidemia Pasien Rawat Jalan di RSUD Prof Dr Margono Soekarjo Purwokerto. Penelitian Kerjasama dengan Badan Penelitian dan Pengembangan Kesehatan Departemen Kesehatan Republik Indonesia.

Rossi, E.A., Vendramini, R.C., Carlos, I.Z., de Olievera, M.G. dan de Valdez, G.F. (2005). Effect of new fermented soy milk product on serum lipid level in normocholesterolemic adult men. Process Biochemistry 40: 1791-1797. 